\title{
Thousand Cankers Disease Complex: A Forest Health Issue that Threatens Juglans Species across the U.S.
}

\author{
Dixie A. Daniels ${ }^{1}$, Katheryne A. Nix ${ }^{2}$, Phillip A. Wadl ${ }^{3}$, Lisa M. Vito ${ }^{2}$, Gregory J. Wiggins ${ }^{2}$, \\ Mark T. Windham ${ }^{2}$, Bonnie H. Ownley ${ }^{2}$, Paris L. Lambdin ${ }^{2}$, Jerome F. Grant ${ }^{2}$, Paul Merten ${ }^{4}$, \\ William E. Klingeman ${ }^{5}$ and Denita Hadziabdic ${ }^{2, *}$ \\ 1 Department of Forest Engineering, Resources \& Management, Oregon State University, 280 Peavy Hall, \\ Corvallis, OR 97333, USA; dixie.daniels@oregonstate.edu \\ 2 Department of Entomology and Plant Pathology, University of Tennessee, 2505 E.J. Chapman Dr., \\ 370 Plant Biotechnology Building, Knoxville, TN 37996-4560, USA; kavery3@utk.edu (K.A.N.); \\ lvito@utk.edu (L.M.V.); wiggybug@utk.edu (G.J.W.); mwindham@utk.edu (M.T.W.); \\ bownley@utk.edu (B.H.O.); plambdin@utk.edu (P.L.L.); jgrant@utk.edu (J.F.G.) \\ 3 United States Department of Agriculture, Agricultural Research Service, United States Vegetable Laboratory, \\ 2700 Savannah Highway Charleston, SC 24914-5334, USA; PHILLIP.WADL@ars.usda.gov \\ 4 United States Department of Agriculture, Forest Service, Forest Health Protection, \\ 200 W.T. Weaver Boulevard, Asheville, NC 28804, USA; pmerten@fs.fed.us \\ 5 Department of Plant Sciences, University of Tennessee, 2431 Joe Johnson Dr., \\ 252 Ellington Plant Sciences Building, Knoxville, TN 37996-4560, USA; wklingem@utk.edu \\ * Correspondence: dhadziab@utk.edu; Tel.: +1-865-974-7135; Fax: +1-865-974-4744
}

Academic Editors: John MacKay and Stephen P. DiFazio

Received: 1 September 2016; Accepted: 29 October 2016; Published: 3 November 2016

\begin{abstract}
Thousand Cankers Disease (TCD) is a disease complex wherein the fungus (Geosmithia morbida) is vectored by the walnut twig beetle (WTB, Pityophthorus juglandis). The disease causes mortality primarily of eastern black walnut (Juglans nigra), although other walnut and wingnut (Pterocarya) species are also susceptible. Black walnut is native to the Eastern and Midwestern U.S. but is widely planted in western states. Total standing volume in both urban and forested settings is approximately 96 million cubic meters, and is valued at $\$ 539$ billion. Although native to the Southwestern U.S., the range of WTB has expanded considerably. The spread of G. morbida coincides with that of WTB. TCD was introduced into Tennessee in 2010, and has spread to seven eastern states. Trees infected with TCD exhibit drought-like symptoms, making field detection difficult without molecular and/or morphological methods. The recently sequenced G. morbida genome will provide valuable research tools focused on understanding gene interactions between organisms involved in TCD and mechanisms of pathogenicity. With no chemical treatments available, quarantine and sanitation are preeminent options for slowing the spread of TCD, although biological control agents have been discovered. High levels of black walnut mortality due to TCD will have far-reaching implications for both eastern and western states.
\end{abstract}

Keywords: eastern black walnut; walnut twig beetle; fungal pathogen; Geosmithia morbida; Juglans nigra; Pterocarya spp.; Pityophthorus juglandis; insect vector; forest health

\section{Introduction}

Currently, Juglans spp. and Pterocarya spp. (Fagales: Juglandaceae) trees across the United States (U.S.) and Europe are threatened by an insect-fungal disease complex known as Thousand Cankers Disease (TCD). The pathogen associated with TCD is a filamentous ascomycete, Geosmithia morbida M. Kolař́k, E. Freeland, C. Utley, \& N. Tisserat (Hypocreales: Bionectriaceae) [1]. The pathogen is vectored primarily by the walnut twig beetle (WTB) Pityophthorus juglandis Blackman (Coleoptera: 
Curculionidae) [1-3]. Another beetle species, Stenomimus pallidus (Boheman) (Coleoptera: Curculionidae), has also been identified as a potential vector of G. morbida in Indiana and Ohio [4,5].

\section{The Thousand Cankers Disease Complex}

Although decline in Juglans spp. was observed in the mid-1990s in the Willamette Valley of Oregon, the first published record and indication of high mortality of J. nigra L. associated with WTB was in the Espanola Valley in New Mexico in 2001 [6]. By 2008, WTB and a then-unknown species of Geosmithia were suspected to cause widespread walnut decline in Colorado, and the term "Thousand Cankers Disease" was proposed to describe the numerous coalescing cankers that form in the phloem area around WTB entrance holes and galleries [2]. In 2011, the fungal pathogen associated with TCD was designated G. morbida [1]. Currently, TCD has become widely distributed among J. nigra and other walnut species across the western U.S. [7]. In 2010, the disease complex was first confirmed within the native range of eastern black walnut in Tennessee [8], followed by Pennsylvania and Virginia in 2011 [9,10], North Carolina in 2012 [11], Ohio in 2013 [12,13], and Maryland and Indiana in $2014[4,14,15]$. The spread of the disease has continued with the first confirmed case of TCD infection in Europe in 2013, found on transplanted eastern black walnut and native English walnut (J. regia L.) in Italy [16,17].

Typical symptoms of TCD include wilting and yellowing of leaves, branch dieback, and canopy loss. Geosmithia morbida spores germinate and reproduce in WTB galleries, forming numerous cankers underneath the bark (Figure 1) [2]. Over time these small dark brown to black cankers coalesce to girdle the tree $[1,2,18]$. Recent research has uncovered a potential relationship between water availability and expression of TCD symptoms, further confounding the detection process [19]. High-stress, low water potential conditions were more likely to coincide with high TCD incidence, while low-stress, high water potential conditions (e.g., a well-drained bottomland site) was more likely to coincide with tree improvement and production of new growth [19]. Because TCD symptoms mimic those of drought, field detection can be difficult if cankers are concealed or have not yet formed (Figure 1). Disease detection is often challenging because of absence of symptoms or signs on the bark surface or due to signs being confused with other abiotic or biotic agents that cause similar symptoms. However, molecular detection of TCD can be confirmed using G. morbida or WTB microsatellite loci while trees are asymptomatic $[20,21]$, thus increasing efficacy and response time to potential epidemic outbreaks.

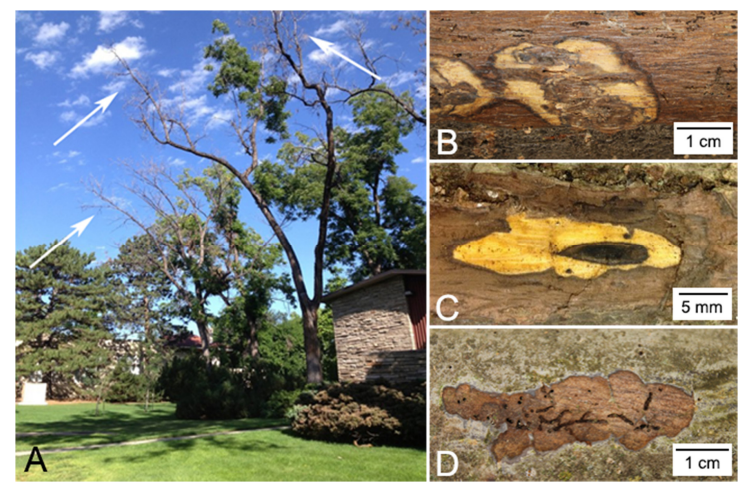

Figure 1. Thousand Cankers Disease symptoms, gallery formation, and canker development. Later stage crown and branch dieback symptoms of Thousand Cankers Disease on Juglans nigra trees (white arrows). Trees exhibit symptoms similar to drought, including flagging and yellowing of leaves, branch dieback, and canopy loss (A); Pityophthorus juglandis galleries and exit holes in the phloem of J. regia branch. Multiple coalescing cankers on J. hindsii have girdled the branch resulting in rapid tree mortality (B); Characteristic elliptical canker associated with Geosmithia morbida infection in J. nigra branch. The cankers are visible only after the outer bark is removed (C); Adult walnut twig beetles create entrance and emergence holes about the size of a pinhead $(0.64-0.75 \mathrm{~mm})$, with galleries approximately $2.5-5 \mathrm{~cm}$ long (D). 


\section{The Host Plant Species}

The tree genus Juglans (walnuts) is considered a north temperate group that contains 16 species of walnuts (Juglans sect. Rhysocaryon) that are endemic to the Americas [22]. Five of those species have a range and distribution in the U.S. (southern California walnut (J. californica S. Wats.; northern California walnut (J. hindsii (Jeps.) Jeps. ex R.E. Sm.), Arizona walnut (J. major (Torr.) A. Heller), Texas walnut (J. microcarpa Berlandier), and eastern black walnut (J. nigra)) [22]. All but Arizona walnut exhibit high sensitivity to pathogen infections [23]. Although all Juglans species are susceptible to TCD infection, eastern black walnut is the most affected by this disease [7]. In the case of severe infection, TCD can result in tree mortality within two to three years after initial symptoms have been observed [2,23]. Eastern black walnut is native to the Eastern and Midwestern U.S. Trees grow singly or in small clusters within forests and at forest edges from Minnesota to Florida, and from the Atlantic coast to central Texas, excluding the Mississippi River Valley [24]. The species is not evenly distributed across its range, with greatest densities of eastern black walnut occurring in Missouri, Ohio, and Kentucky [25]. Site conditions most suitable for eastern black walnut growth include deep, well-drained soils, an average annual temperature of around $13^{\circ} \mathrm{C}$, and average annual precipitation above $890 \mathrm{~mm}$ [24].

Using species specific microsatellite loci, Victory et al. [26] found high genetic diversity and homogeneity among eastern black walnut populations from the central hardwood region of the U.S. They hypothesized that evidence of a single Bayesian group can be explained by recolonization of eastern black walnut from a single glacial refugium and high levels of gene flow and gene dispersal across wide geographical ranges [26]. Boraks and Broders found similar pattern of low genetic differentiation and high diversity in butternut (J. cinerea L.) populations [27]. They found that despite wide-range population collapse due to introduced fungal pathogen Ophiognomonia clavigignenti-juglandacearum (V.M.G. Nair, Kostichka \& J.E. Kuntz) Broders \& Boland (Diaporthales: Gnomoniaceae), significant historical gene flow exists among butternut stands $[27,28]$. On the other hand, major shifts in population demography resulting from a rapid population decline can result in substantial loss of genetic diversity and increased genetic differentiation [29,30]. It is currently unclear to what extent these changes are occurring in Juglans spp. as a result of different ecological processes, including various disease pressures and anthropogenic activities. Regardless, greater understanding about existing genetic diversity within Juglans species is expected to provide a baseline from which pathogen virulence can be assessed against walnut host species and clonal germplasm within species with a long-term goal of exploiting disease resistance in future tree breeding efforts.

Eastern black walnut has also been introduced to the western U.S., where it is planted as an ornamental tree and used as root-stock for grafting scions of English walnut. These grafted trees of English walnut are resistant to soil-borne pathogens that would kill English walnut trees growing from their own roots [31]. Juglans nigra is an important wildlife resource across the various ecoregions and habitats in which it occurs [8]. The species provides a food resource for animals, and a source of nuts and timber for humans, and loss of this tree species would have a significant ecological, economic, and aesthetic impact in production sectors such as timber harvest, furniture manufacturing, nut crops, and nursery stock production $[3,8]$. It has been estimated that the net volume of eastern black walnut growing stock on timberland is between 96 and 112 million cubic meters [25,31]. This figure accounts only for eastern black walnut trees growing within the native range, and does not include transplanted trees grown in the Western U.S. In general, eastern black walnut that are categorized as growing stock are eventually harvested for lumber and veneer. For these reasons, volume measurements are considered most appropriate. As of 2009, this growing stock had an estimated standing value of approximately $\$ 539$ billion [31], and the wood is among the most highly prized for its physical and mechanical properties, as well as its ease of use in woodworking applications [32]. In addition to the economic value of wood products, walnut oils and extracts are used in a variety of areas benefiting society such as in food products, medicine, and the industrial complex [24]. Expanded incidence of TCD into the native range of eastern black walnut is also expected to result in substantial costs associated with tree removal for those homeowners who have black walnuts on their properties. 
Although Juglans species are the principal host plant under threat, wingnut species (Pterocarya spp.) are also recognized as host plants that are challenged by this disease complex in California, and could threaten trees in Louisiana, Missouri, and North Carolina where the principally Asian and Caucasian (native to Iran, Turkey, and Syria) species in the genus may occasionally be found as a street and landscape shade tree species [33].

\section{The Plant Pathogen}

Geosmithia morbida is a slow-growing pathogenic, filamentous ascomycete fungus (Figure 2). This species was previously thought to be the only pathogenic species in the genus, until G. pallida (G. Sm.) M. Kolarík, Kubátová \& Paotová was discovered to cause Foamy Bark Canker on Coast Live Oak (Quercus agrifolia Nee) (Fagales: Fagaceae) [34]. Most Geosmithia spp. are bark beetle symbionts and have not been reported as significant plant pathogens [3]. When G. morbida was first characterized, fungal isolates from seven western states were used. Arizona, California, Colorado, Idaho, Oregon, Utah, and Washington were already experiencing mortality of walnut trees by the time the pathogen was identified [1].

The G. morbida genome (26.5 Mbp) has recently been sequenced, revealing less than $1 \%$ repetition within its more than 6000 genes [35]. A genome-enabled research approach focused on G. morbida can provide a better understanding of the biology of the pathogen involved in TCD and identify candidate genes and functions required for pathogenesis. In other plant pathogen systems, whole genome sequencing revealed a number of highly polymorphic regions which allowed the pathogen to quickly adapt to new hosts or environments [36], decrease host disease resistance [37], and allowed researchers to manipulate certain gene clusters that could alter the virulence of the pathogen [38]. Without an insight into the pathogenicity and mechanisms by which G. morbida overcomes walnut defenses, our ability to predict, prevent, and manage TCD epidemics will be extremely limited. Thus, additional genomic research based on Schuelke et al. will serve as a valuable tool for further investigation into the pathogenesis of G. morbida and related forest diseases [35].

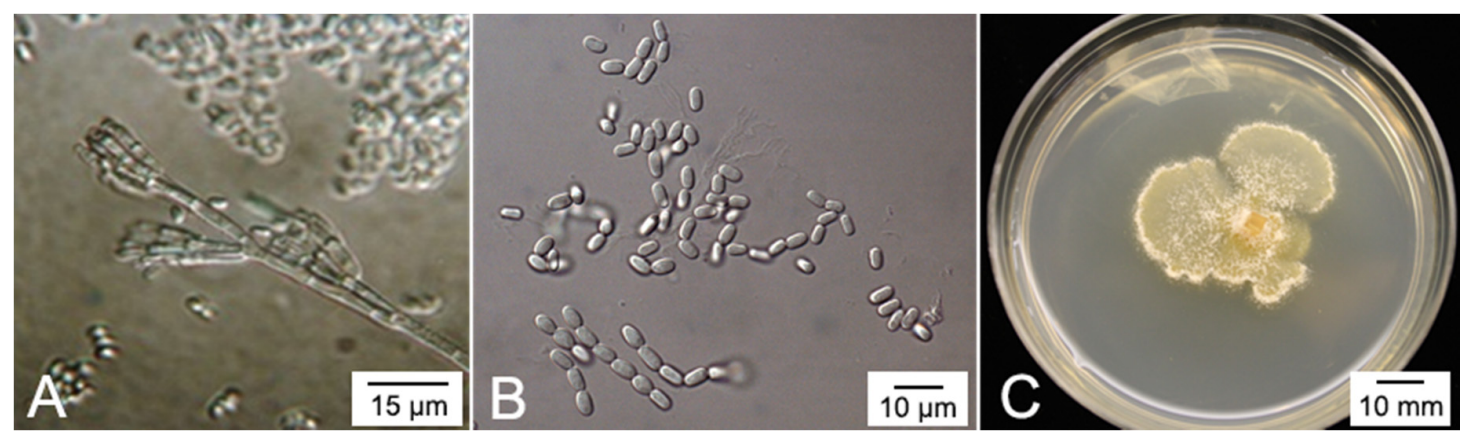

Figure 2. The fungal pathogen of Thousand Cankers Disease, Geosmithia morbida. Light micrograph image of G. morbida conidiophores (A) and conidia (B); G. morbida isolate grown in $10 \%$ potato dextrose agar plate $(\mathbf{C})$.

Geosmithia morbida has a wide host range that includes other Juglans species, although eastern black walnut is the most susceptible host plant [7]. Three Carya spp. (Carya illinoinensis (Wangenh.) K. Koch, C. aquatica (F.Michx.) Nutt. and C. ovata (Mill.) K.Koch) (Fagales: Juglandaceae) were tested for susceptibility to TCD, but were found to be immune to G. morbida infection [7]. Additionally, three species of wingnut in California have recently been shown to express symptoms of TCD: Pterocarya fraxinifolia (Lam.) Spach, P. rhoifolia Siebold \& Zucc.; and P. stenoptera C. DC [33]. It should be noted that none of the Pterocarya spp. are found in forested settings in the U.S. Recently, English walnut, an important species for California walnut production, has also exhibited serious TCD disease symptoms [39]. 
The origin of G. morbida is currently unknown, but its spread has been widely documented to coincide with the range and spread of WTB $[2,3,8,12,16,40]$. Two different hypotheses were provided by Zerillo et al. [3] regarding G. morbida point of origin that coincide with native range and distribution of either Arizona or California walnut trees. Although research progress has been made in elucidating these questions and additional work remains in progress, high genetic diversity and the complexity of the pathogen suggest that $G$. morbida has been in association with at least one the walnut species and its vector for a long period of time $[3,40]$. Indeed, these latter studies both examined population structure and genetic diversity of the pathogen, and their results indicate high genetic diversity and the presence of between two [40] and four [3] genetic clusters, which corresponded to geographical distribution among G. morbida isolates in the U.S. Zerillo et al. [3] found no evidence of sexual reproduction, and described strong evidential support to indicate that G. morbida has evolved in close association with WTB and at least one walnut species. In a related study by Freeland [41], twelve distinct haplotypes were identified from walnut samples collected from nine states. The virulence and canker forming abilities of these haplotypes were determined to be similar enough that specific G. morbida isolates are not necessary for epidemiological or genetic research [41]. This report further indicated high genetic diversity of the pathogen, thus confirming the hypothesis of multiple introductions from multiple sources [3,39]. Both Zerillo et al. [3] and Hadziabdic et al. [40] proposed that anthropogenic movement of timber from multiple TCD infested areas, coupled with high susceptibility of eastern black walnut to disease pressures [7] would support the hypothesis that the pathogen has been recently introduced into the eastern U.S.- the native range of eastern black walnut. This scenario has been observed in other forest pathogen systems, particularly the expansion of non-native pathogens into native forest communities [42,43]. These novel introductions pose a major risk due to absence of co-evolutionary encounters and evolutionary potential of the pathogen, and lack of detection due to cryptic symptoms, thus allowing migration and admixture of populations to occur and therefore potentially increase genetic diversity $[3,40,44,45]$.

\section{The Principle Vector}

Currently known to be the most prolific vector of G. morbida [1-3,23], WTB, Pityophthorus juglandis is a small $(1.5-1.9 \mathrm{~mm})$ light brown beetle that for a long time was found only in the Southwestern U.S. (Figure 3). The species was originally described from specimens collected in Lone Mountain, New Mexico and Arizona, on eastern black walnut in 1928 [46]. This beetle is native to Chihuahua (Mexico), Arizona, California, and New Mexico [2,31,47,48]. Although the initial distribution of WTB was limited to Mexico and the southwestern U.S. [46], in the past decade it's range expanded to include Colorado, Idaho, Nevada, Oregon, Utah, and Washington in the western U.S. [23,49]. In the eastern U.S., WTB was first found in Knoxville, Tennessee in July 2010 [8,50]. As of 2015, WTB has been confirmed in an additional seven states: Indiana, Maryland, North Carolina, Ohio, Pennsylvania, Tennessee, and Virginia [14,23].

Within the native range of WTB, the primary host is Arizona walnut J. major, whereas southern California walnut (J. californica) may serve as host where distributions of host species overlap [49,51]. At the Unites States Department of Agriculture-Agricultural Research Service (USDA-ARS) germplasm collection in Davis, California, WTB have been collected from several Juglans species, including southern California walnut (J. californica), northern California walnut (J. hindsii), eastern black walnut (J. nigra), and English walnut (J. regia), as well as the exotic nogal criollo (J. australis Griseb.) and J. mollis Engelm. [52]. Rugman-Jones et al. argued that the most likely scenario explaining WTB expansion occurred from California, either by beetle spreading or human mediated movement to other western U.S. states [23]. High levels of genetic diversity and evidence of two genetic lineages among WTB in the U.S. have been found, prompting the authors to suggest that the evidence may support presence of two morphologically indistinguishable species within P. juglandis [23]. High diversity levels are expected at an organism's point of geographical origin; validation of this expectation provides additional support for the hypothesis of co-evolution of the beetle with native Arizona walnut or California 
walnut hosts [3,23]. According to Rugman-Jones et al., two major haplotypes within one of those two lineages are responsible for the increasing range, yet hybridization that occurs among the haplotypes is predicted to be a relatively recent evolutionary event [23]. Though the recent hybridization postulated by Rugman-Jones et al. is between two highly divergent lineages, "hybridization" between individuals possessing different mitochondrial haplotypes within each of those divergent lineages (i.e., sex) has probably been going on for some time. Regardless, WTB was first documented in relation to eastern black walnut mortality in Colorado in 2001 [2] and described as the primary vector of the TCD complex in 2011 [1].
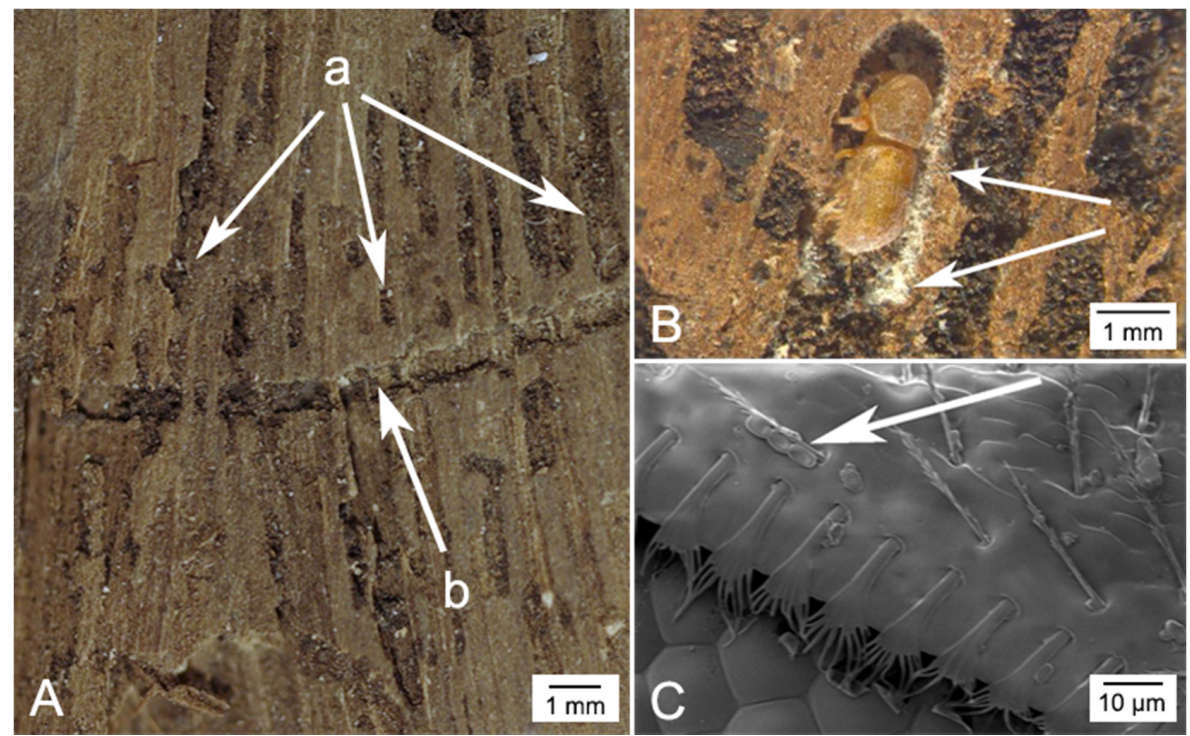

Figure 3. Thousand Cankers Disease vector, Pityophthorus juglandis. Teneral P. juglandis adult gallery formation in Juglans nigra branch. Adult galleries are horizontal (a), larval galleries are vertical (b) (A); Closer examination of P. juglandis gallery. Note Geosmithia morbida mycelium surrounding P. juglandis gallery (arrows) (B); Scanning electron microscope image of P. juglandis with G. morbida conidia (arrow) (C).

Adult male WTB larvae and adults overwinter within host trees [53,54]. Emergence generally occurs between January and March, followed by a primary flight phase between May and July, and a secondary flight phase from September to October. Male WTB scout for suitable host trees by identifying volatile organic compounds (VOCs), which are host-specific odors that WTB can detect $[23,55]$. Once they find an appropriate host plant, the males release pheromones to attract other WTB to initiate mass attack and mating. Females lay eggs in the phloem of host trees. Larvae tunnel through the phloem and form vertical galleries along the wood grain, while adults create galleries horizontally along the cambial layer (Figure 2). Adult WTB create entrance and emergence holes about the size of a pinhead $(0.64-0.75 \mathrm{~mm}$ ), with galleries approximately $2.5-5 \mathrm{~cm}$ long (Figure 2) [56,57]. The holes and galleries created by a WTB infestation produce myriad infection courts for G. morbida. WTB do not possess mycangia, which are internal organs adapted for the transport of fungi. Instead, fungi are carried externally or potentially internally, and beetles deposit G. morbida spores on host plant tissues as adults bore through the bark into the phloem of the tree (Figure 2) [51].

A better understanding of the olfactory relationship between host and vector has resulted in a number of effective trapping systems. WTB can be trapped using pheromones, VOCs, or a combination of both. Hadziabdic et al. [11] used a system of trapping that combined a pheromone-baited funnel trap with a bundle of eastern black walnut branches hanging nearby. Girdling eastern black walnut branches to instigate the release of VOCs is another effective lure for WTB. According to Ginzel, adult WTB are also attracted to the VOCs of G. morbida [55]. 
Diurnal flight is bimodal, but the majority of flight activity (more than 75\%) occurs near dusk. Crepuscular flight is influenced by multiple abiotic factors including temperature, light intensity, barometric pressure, and wind speed [58]. In a study of the effects of temperature on WTB survival, Luna et al. established three temperature thresholds for adult WTB and larvae [59]. The super-cooling point (SCP) of WTB is the temperature at which spontaneous intracellular freezing occurs, between $-14.4^{\circ} \mathrm{C}$ and $-19.7^{\circ} \mathrm{C}$ depending on the season. The lower median lethal temperature $\left(L T_{50}\right)$, the median temperature at which WTB will die from cold, was $-16.7^{\circ} \mathrm{C}$ for adults and $-16.9{ }^{\circ} \mathrm{C}$ for larvae. The upper median $L T_{50}$, the median temperature at which WTB will die from heat, was established at $47.9^{\circ} \mathrm{C}$ for adults and $47.3^{\circ} \mathrm{C}$ for larvae [59]. Extreme low air temperatures were observed in conjunction with the low-pressure polar vortex conditions experienced starting January 2014 and lasting into March. If temperatures below the $L T_{50}$ threshold were sustained beneath the bark of eastern black walnut trees in the eastern U.S., cold-induced WTB mortality, perhaps paired with interactions with natural enemy arthropods, may help explain declines in WTB subsequently captured in aggregation pheromone-baited traps. In Tennessee, population levels of WTB were lower for 2014 across locations that beetles had been continuously monitored and trap yields for WTB have continued to decline into 2016 (W. Klingeman, P. Lambdin, and G. Wiggins) [60].

\section{Alternative and Secondary Pathogens and Pathogen Vectors}

Although G. morbida has been determined to be the primary pathogen of the TCD complex, there is limited research regarding secondary or opportunistic pathogens associated with TCD. Other fungi found to be associated with this disease complex, such as Fusarium solani (Mart.) Sacc., (Order: Family) are known to cause cankers in eastern black walnut [61] as well as other tree species, including English walnut, red oak (Quercus rubra L.), and cottonwood (Populus deltoides W. Bartram ex Humphry Marshall) (Malpighiales: Salicaceae) [62-64]. The first report of F. solani on eastern black walnut was given by Tisserat et al. [61]. Previous assertions were made that $F$. solani attacked weakened trees during the later stages of TCD infection [65]. More recent findings indicate that $F$. solani may act instead as an early colonizer and a contributing pathogen of TCD-infected walnut trees in the early stages of disease development [17]. Current knowledge regarding a F. solani and G. morbida synergistic pathosystem is limited and should be more closely characterized to elucidate the range of host-pathogen interactions occurring within this disease complex.

Other Coleopteran species also attack eastern black walnut, including ambrosia beetles such as Xylosandrus germanus (Blandford) and Xylosandrus crassiusculus (Motschulsky) (Coleoptera: Curculionidae), bark beetles including Dryoxylon onoharaensum (Murayama) and Pityophthorus lautus Eichhoff (Coleoptera: Curculionidae), and weevils such as Himatium errans LeConte and Sitophilus zeamais Motschulsky (Coleoptera: Curculionidae) [55]. Fourteen species of ambrosia beetles were found in eastern black walnut samples collected from Indiana and Missouri, as well as four bark beetle species, and four weevil species [55]. Among the weevils found, S. pallidus has been associated with G. morbida at a number of sites in Indiana [5]. A more complete characterization of arthropods that may potentially play a role in vectoring G. morbida, and sustaining some degree of transmission into walnut is ongoing.

\section{Impact/Influence of Natural Enemies}

Lambdin et al. [57] investigated natural enemies of WTB in an attempt to establish one or more species as a potential biological control agent. They discovered fourteen predatory insects and two parasitoid wasp species in eastern black walnut samples collected from East Tennessee. In addition, they assessed feeding capabilities of two Cleridae species, Madoniella dislocatus (Say) and Pyticeroides laticornis (Say) (Coleoptera: Cleridae). Madoniella dislocatus is a generalist predator, while P. laticornis primarily feeds on bark beetles. These clerid beetle species are widely distributed within the eastern U.S., with M. dislocatus also found in Colorado [66,67]. In laboratory feeding assays, both beetle species showed a strong preference for live WTB, and preferred WTB over other potential prey species 
Xylosandrus crassiusculus and Tribolium confusum Jacquelin du Val (Coleoptera: Tenebrionidae) [57]. The authors concluded that $M$. dislocatus may make a more effective predator than P. laticornis due to its preference for smaller prey, and its calm disposition that would lend itself to easier population rearing in a laboratory setting [57].

\section{Forest Health Implications}

Eastern black walnut confers a limited yet important role in sustaining the health and diversity of eastern deciduous forest ecosystems. This species is an important hardwood timber tree and has served as a valued ornamental and root stock species in western states. The standing density of eastern black walnut trees occurring across the native range is highly variable, from somewhat high density in Midwestern forests (accounting for 35\% of all living eastern black walnut trees within the native range) to very low density in Southern forests [25]. Even with variable densities, the loss of eastern black walnut would have a serious and immediate biological impact on forest communities, and an economic impact on arboricultural and agricultural communities [31]. While most research on TCD-infected eastern black walnut focuses on trees in urban or forest edge environments, it is important to address TCD as it relates to eastern black walnut within forests. In one study, sixteen pheromone-baited funnel traps were deployed on or near eastern black walnuts in forested areas to assess the impact of TCD near locations where the disease had been detected. WTB were collected from four traps [68]. In an earlier study, G. morbida was found at the forest edge and WTB were later collected nearby, in the wooded interior [11].

Three factors make TCD potentially devastating to eastern black walnut populations across the U.S.: high susceptibility of all Juglans species to TCD, the apparent ease with which fungus and vector can be transported via natural or anthropomorphic means, and the variety of geographic and climatic conditions in which G. morbida can survive. In addition to these three factors, wildlife relies on annual walnut production, particularly in years when acorn production is low [8]. The loss of eastern black walnut in forests would also impact species richness. Further, eastern black walnut mortality would be detrimental to the walnut log market, impacting export and domestic commerce in furniture manufacturing, very-high value lumber, and veneer production [31].

\section{Control Measures}

The first line of regulatory defense for prevention of TCD movement into new areas is to quarantine eastern black walnut wood from leaving areas of TCD infection. Within a quarantined area, unprocessed walnut wood, such as firewood or wood that has not yet been processed into lumber, may not be transported outside the quarantine zone. In many, but not all quarantined areas, once walnut wood has been processed, it may be exported out of the quarantine zone. Processing can consist of heat treatment, chemical treatment, kiln-drying, or cutting the wood into lumber [69]. In the case of TCD quarantines, the danger in transporting unprocessed wood lies within the bark of the tree, where WTB construct their galleries. Treated wood with intact bark may still be at risk for WTB attack [70,71], so additional safeguards should be considered when transporting treated eastern black walnut wood with intact bark [71,72]. If processing is unsuccessful in removing WTB, eastern black walnut should be destroyed within the quarantine area.

Nine Tennessee counties with confirmed TCD infection have been quarantined [73]. Ohio, Virginia, North Carolina, and Pennsylvania have subsequently enacted their own quarantines [9,74-76]. Other states without infestations of WTB or confirmation of G. morbida infected wood, such as Minnesota, have banned the import of walnut material from infected states [77]. Despite quarantine efforts, TCD has continued to spread. Maryland is the most recent state to find both WTB and G. morbida, and has enacted a quarantine in the affected county [14].

Chemical treatment with insecticides has demonstrated only limited efficacy, and is suitable only for high-value trees [78], including cut logs [72]. Because eastern black walnut trees produce nuts that are consumed by humans, the available chemical control options for living trees are severely 
limited. Imidacloprid and dinotefuran, both broad-spectrum insecticides currently used in bark beetle management, can arrest the spread of TCD by eliminating the vector [54]. However, neither chemical is approved for use on eastern black walnut due to its classification as a food-producing tree [79]. Residual concentrations of imidacloprid were found throughout various tree tissues, including in the nuts and husks. In an identical test, dinotefuran was found in very small concentrations in some parts of the tree, but was absent in nut meat [80]. However, these two chemicals are not without controversy. Imidacloprid and dinotefuran are both neonicotinoid-class chemicals [81,82]. Neonicotinoids are controversial for use in forest and agricultural settings due to high toxicity to bees. This class of chemicals has additionally been implicated in bee colony collapse disorder [83].

Another possible TCD control agent could come in the form of entomopathogenic fungi, fungi that cause disease or mortality in insects. Two fungal species are likely candidates for control: Beauveria bassiana (Bals.-Criv.) Vuill. (Hypocreales: Cordycipitaceae) and Metarhizium anisopliae (Metschn.) Sorokin (Hypocreales: Clavicipitaceae) [84]. These fungi have historically been used in the control of soil inhabiting insects, yet recent studies have also looked to B. bassiana and M. anisopliae for biological control of Coleopteran species [83-87]. These entomopathogens are also endophytes, fungi that live within the tissues of plants $[88,89]$. The existence of beneficial or neutral endophytes within a plant may also prevent pathogenic fungi from causing damage [88-92]. The combination of insect-killing plus pathogen protection makes these entomopathogenic fungi particularly interesting in the light of the complicated TCD disease complex.

Successful mitigation of TCD might be best accomplished using a combination of approaches that include:

1. Increased training, both for Extension agents who can inform and encourage citizen participation in eastern black walnut protection, and for professional foresters/arborists who can take steps to protect eastern black walnut in their managed forest communities;

2. Increased industry and government oversight that includes directed enforcement of quarantines to limit walnut wood movement outside of containment areas;

3. Additional research, with emphases focusing on optimized trapping protocols for P. juglandis and exploitation and enhancement of natural enemy predators and parasitoids across the range of J. nigra;

4. Greater understanding of the synergistic pathosystem between F. solani and G. morbida elucidating host-pathogen interactions occurring via this disease complex;

5. Genome-enabled research approaches focused on G. morbida that are expected to provide a better understanding of the biology of the pathogens involved in TCD and will help identify candidate genes and functions required in pathogenesis.

The loss of eastern black walnut will have significant environmental and economic impacts on both forest and urban settings throughout the U.S. Species richness and wildlife forage in forests will be impacted, especially in areas where density of eastern black walnut populations is higher. In addition, the loss of this very high-value species will lead to economic distress, as well as negative social and cultural effects in impacted areas. Within the native range and possibly in western states as well, water availability and stress have a discernable impact on overall survival of individual trees [19]. Identification and mitigation of TCD infection is paramount given anticipated hydrologic climate change, wherein incidence of TCD expression is predicted to increase alongside drought conditions in the U.S. [93,94]. Setting up quarantine zones is the first step to slow the extent of transmission. Sanitation of diseased trees can also stop the spread of TCD. Treatment of TCD-infected trees with established insecticides is effective against WTB, but some compounds are not permitted due to use of eastern black walnut as a food crop. Without a concerted effort to understand all of the biotic and abiotic conditions that contribute to TCD, the detection methods outlined above will only be marginally effective in the prevention and mitigation of this economically significant plant disease. 
Acknowledgments: The authors thank United States Forest Service (Grant number 13-DG-11083150-033) and United States Forest Service-Special Technology Development Program (Grant numbers 13-DG-11083150-039) for partial financial support. This work is also supported, in part, by the USDA National Institute of Food and Agriculture, Hatch project 1009630 and the United States Department of Agriculture (Grant number 2015-70006-24159). Special thanks to research assistants and associates, as well as graduate and undergraduate students for their support to ongoing research efforts, enthusiasm, and for furthering knowledge regarding TCD. The authors additionally thank independent reviewers for their comments and suggestions for manuscript improvement. Thanks also to Dr. Jim Kiser for guidance and suggestions. Finally, the authors thank Lisa M. Vito, author on this paper who passed away before publishing. Her contributions to plant pathology will be remembered.

Author Contributions: Dixie A. Daniels wrote the manuscript and provided images for use. Denita Hadziabdic assisted in writing and editing of the manuscript, and provided images for use. Katheryne A. Nix assisted in editing, and provided images for use. William E. Klingeman, Paris L. Lambdin, Bonnie H. Ownley, Lisa M. Vito, Phillip A. Wadl, Gregory J. Wiggins, Jerome F. Grant, and Mark T. Windham assisted in writing and editing of the manuscript.

Conflicts of Interest: The authors declare no conflict of interest.

\section{References}

1. Kolarík, M.; Freeland, E.; Utley, C.; Tisserat, N. Geosmithia morbida sp. nov., a new phytopathogenic species living in symbiosis with the walnut twig beetle (Pityophthorus juglandis) on Juglans in USA. Mycologia 2011, 103, 325-332. [CrossRef] [PubMed]

2. Tisserat, N.; Cranshaw, W.; Leatherman, D.; Utley, C.; Alexander, K. Black walnut mortality in Colorado caused by the walnut twig beetle and thousand cankers disease. Plant Health Prog. Publ. 2009. [CrossRef]

3. Zerillo, M.M.; Caballero, J.I.; Woeste, K.; Graves, A.D.; Hartel, C.; Pscheidt, J.W.; Tonos, J.; Broders, K.; Cranshaw, W.; Seybold, S.J.; et al. Population Structure of Geosmithia morbida, the Causal Agent of Thousand Cankers Disease of Walnut Trees in the United States. PLoS ONE 2014, 9, e0112847. [CrossRef] [PubMed]

4. Warmund, M.; van Sambeek, J. Thousand cankers disease: Geosmithia morbida spores isolated from a weevil. Mo. Environ. Gard. 2014, 20, 3. Available online: http://www.treesearch.fs.fed.us/pubs/46063 (accessed on 12 August 2016).

5. Juzwik, J.; Banik, M.T.; Reed, S.E.; English, J.T.; Ginzel, M.D. Geosmithia morbida found on Weevil Species Stenomimus pallidus in Indiana. Plant Health Prog. 2015, 16, 7-10. [CrossRef]

6. Tisserat, N.; Cranshaw, W.; Putnam, M.L.; Pscheidt, J.; Leslie, C.A.; Murray, M.; Hoffman, J.; Barkley, Y.; Alexander, K.; Seybold, S.J.; et al. Thousand Cankers Disease Is Widespread in Black Walnut in the Western United States. Plant Health Prog. 2011, 10, 1094. [CrossRef]

7. Utley, C.; Nguyen, T.; Roubtsova, T.; Coggeshall, M.; Ford, T.M.; Grauke, L.J.; Graves, A.D.; Leslie, C.A.; McKenna, J.; Woeste, K.; et al. Susceptibility of Walnut and Hickory Species to Geosmithia morbida. Plant Dis. 2013, 97, 601-607. [CrossRef]

8. Grant, J.F.; Windham, M.T.; Haun, W.G.; Wiggins, G.J.; Lambdin, P.L. Initial assessment of Thousand Cankers Disease on Black walnut, Juglans nigra, in eastern Tennessee. Forests 2011, 2, 741-748. [CrossRef]

9. Thousand Cankers Disease. Available online: http://www.agriculture.pa.gov/Protect/PlantIndustry/TCD/ Pages/default.aspx (accessed on 12 August 2016).

10. Hansen, M.A.; Bush, E.; Day, E.; Griffin, G.; Dart, N. Walnut Thousand Cankers Disease Alert. Available online: http:/ / www.vdacs.virginia.gov/pdf/techpestalert.pdf (accessed on 12 August 2016).

11. Hadziabdic, D.; Windham, M.; Baird, R.; Vito, L.; Cheng, Q.; Grant, J.; Lambdin, P.; Wiggins, G.; Windham, A.; Merten, P.; et al. First Report of Geosmithia morbida in North Carolina: The Pathogen Involved in Thousand Cankers Disease of Black walnut. Plant Dis. 2013, 98, 992. [CrossRef]

12. Fisher, J.R.; McCann, D.P.; Taylor, N.J. Geosmithia morbida, thousand cankers disease of black walnut pathogen, was found for the first time in southwestern Ohio. Plant Health Prog. 2013. [CrossRef]

13. Juzwik, J.; McDermott-Kubeczko, M.; Stewart, T.J.; Ginzel, M.D. First Report of Geosmithia morbida on Ambrosia Beetles Emerged from Thousand Cankers-diseased Juglans nigra in Ohio. Plant Dis. 2016, 100, 1238. [CrossRef]

14. Walnut Twig Beetle and Thousand Cankers Disease. Available online: http://mda.maryland.gov/plantspests/Pages/tcd.aspx (accessed on 15 August 2016). 
15. Ginzel, M.; Juzwik, J. Geosmithia morbida, the Causal Agent of Thousand Cankers Disease, Found in Indiana. Available online: http:/ / www.treesearch.fs.fed.us/pubs/46047 (accessed on 25 July 2016).

16. Montecchio, L.; Faccoli, M. First record of Thousand Cankers Disease Geosmithia morbida and walnut twig beetle Pityophthorus juglandis on Juglans nigra in Europe. Plant Dis. 2014, 98, 696. [CrossRef]

17. Montecchio, L.; Faccoli, M.; Short, D.; Fanchin, G.; Geiser, D.; Kasson, M.T. First Report of Fusarium solani phylogenetic species 25 associated with early stages of Thousand Cankers Disease on Juglans nigra and Juglans regia in Italy. Plant Dis. 2015, 99, 1183. [CrossRef]

18. Cranshaw, W.; Tisserat, N. Pest Alert Walnut Twig Beetle and Thousand Cankers Disease of Black walnut. Colo. State Univ. 2010. Available online: http://extension.colostate.edu/docs/pubs/insect/1008_alert.pdf (accessed on 29 July 2016).

19. Griffin, G.J. Status of thousand cankers disease on eastern black walnut in the eastern United States at two locations over 3 years. For. Pathol. 2015, 45, 203-214. [CrossRef]

20. Hadziabdic, D.; Wadl, P.A.; Vito, L.M.; Boggess, S.L.; Scheffler, B.E.; Windham, M.T.; Trigiano, R.N. Development and characterization of sixteen microsatellite loci for Geosmithia morbida, the causal agent of thousand canker disease in black walnut (Juglans nigra). Conserv. Genet. Resour. 2012, 4, 287-289. [CrossRef]

21. Hadziabdic, D.; Wadl, P.A.; Staton, M.E.; Klingeman, W.E.; Moulton, J.K.; Pscheidt, J.W.; Wiggins, G.J.; Grant, J.F.; Lambdin, P.L.; Windham, M.T.; et al. Development of microsatellite loci in Pityophthorus juglandis, a vector of thousand cankers disease in Juglans spp. Conserv. Genet. Resour. 2015, 7, 431-433. [CrossRef]

22. Stone, D.E.; Oh, S.-H.; Tripp, E.A.; Rios G, L.E.; Manos, P.S. Natural history, distribution, phylogenetic relationships, and conservation of Central American black walnuts (Juglans sect. Rhysocaryon). J. Torrey Bot. Soc. 2009, 136, 1-25. [CrossRef]

23. Rugman-Jones, P.F.; Seybold, S.J.; Graves, A.D.; Stouthamer, R. Phylogeography of the Walnut Twig Beetle, Pityophthorus juglandis, the Vector of Thousand Cankers Disease in North American Walnut Trees. PLoS ONE 2015, 10, e0118264. [CrossRef] [PubMed]

24. Williams, R.D. Juglans nigra L.; black walnut. In Silvics of North America, 2nd ed.; Burns, R.M., Honkala, B.H., Eds.; U.S. Department of Agriculture, Forest Service: Washington, DC, USA, 1990; Volume 2, pp. 391-399.

25. Randolph, K.C.; Rose, A.K.; Oswalt, C.M.; Brown, M.J. Status of black walnut (Juglans nigra L.) in the eastern United States in light of the discovery of thousand cankers disease. Castanea 2013, 78, 2-14. [CrossRef]

26. Victory, E.R.; Glaubitz, J.C.; Rhodes, O.E., Jr.; Woeste, K.E. Genetic homogeneity in Juglans nigra (Juglandaceae) at nuclear microsatellites. Am. J. Bot. 2006, 93, 118-126. [CrossRef]

27. Boraks, A.; Broders, K.D. Population genetic diversity of the rare hardwood butternut (Juglans cinerea) in the northeastern USA. Tree Genet. Genomes 2016, 12, 43. [CrossRef]

28. Parks, A.; Jenkins, M.; Ostry, M.; Zhao, P.; Woeste, K. Biotic and abiotic factors affecting the genetic structure and diversity of butternut in the southern Appalachian Mountains, USA. Tree Genet. Genomes 2014, 10, 541-554. [CrossRef]

29. Frankham, R. Conservation genetics. Annu. Rev. Genet. 1995, 29, 305-327. [CrossRef] [PubMed]

30. Hoban, S.M.; Borkowski, D.S.; Brosi, S.L.; McCleary, T.S.; Thompson, L.M.; McLachlan, J.S.; Pereira, M.A.; Schlarbaum, S.E.; Romero-Severson, J. Range-wide distribution of genetic diversity in the North American tree Juglans cinerea: A product of range shifts, not ecological marginality or recent population decline. Mol. Ecol. 2010, 19, 4876-4891. [CrossRef] [PubMed]

31. Newton, L.; Fowler, G.; Neeley, A.; Schall, R.; Takeuchi, Y. Pathway Assessment: Geosmithia sp. and Pityophthorus juglandis Blackman Movement from the Western into the Eastern United States. Available online: http://agriculture.mo.gov/plants/pdf/tc_pathwayanalysis.pdf (accessed on 29 July 2016).

32. Voulgaridis, V.; Vassiliou, V.G. The Walnut Wood and its Utilisation to High Value Products. In V International Walnut Symposium 705; International Society for Horticultural Science: Leuven, Belgium, 2005; pp. 69-81. [CrossRef]

33. Hishinuma, S.M.; Dallara, P.L.; Yaghmour, M.A.; Zerillo, M.M.; Parker, C.M.; Roubtsova, T.V.; Nguyen, T.L.; Tisserat, N.A.; Bostock, R.M.; Flint, M.L.; et al. Wingnut (Juglandaceae) as a new generic host for Pityophthorus juglandis (Coleoptera: Curculionidae) and the thousand cankers disease pathogen, Geosmithia morbida (Ascomycota: Hypocreales). Can. Entomol. 2016, 148, 83-91. [CrossRef]

34. Lynch, S.C.; Wang, D.H.; Mayorquin, J.S.; Rugman-Jones, P.F.; Stouthamer, R.; Eskalen, A. First Report of Geosmithia pallida Causing Foamy Bark Canker, a New Disease on Coast Live Oak (Quercus agrifolia), in Association with Pseudopityophthorus pubipennis in California. Plant Dis. 2014, 98, 1276. [CrossRef] 
35. Schuelke, T.A.; Westbrook, A.; Broders, K.; Woeste, K.; MacManes, M.D. De novo genome assembly of Geosmithia morbida, the causal agent of thousand cankers disease. PeerJ 2016, 4, e1952. [CrossRef] [PubMed]

36. Cuomo, C.A.; Güldener, U.; Xu, J.-R.; Trail, F.; Turgeon, B.G.; Pietro, A.D.; Walton, J.D.; Ma, L.-J.; Baker, S.E.; Rep, M.; et al. The Fusarium graminearum Genome Reveals a Link Between Localized Polymorphism and Pathogen Specialization. Science 2007, 317, 1400-1402. [CrossRef] [PubMed]

37. Kämper, J.; Kahmann, R.; Bölker, M.; Ma, L.-J.; Brefort, T.; Saville, B.J.; Banuett, F.; Kronstad, J.W.; Gold, S.E.; Müller, O.; et al. Insights from the genome of the biotrophic fungal plant pathogen Ustilago maydis. Nature 2006, 444, 97-101. [CrossRef] [PubMed]

38. Tyler, B.M.; Tripathy, S.; Zhang, X.; Dehal, P.; Jiang, R.H.Y.; Aerts, A.; Arredondo, F.D.; Baxter, L.; Bensasson, D.; Beynon, J.L.; et al. Phytophthora Genome Sequences Uncover Evolutionary Origins and Mechanisms of Pathogenesis. Science 2006, 313, 1261-1266. [CrossRef] [PubMed]

39. Yaghmour, M.A.; Nguyen, T.L.; Roubtsova, T.V.; Hasey, J.K.; Fichtner, E.J.; DeBuse, C.; Seybold, S.J.; Bostock, R.M. First report of Geosmithia morbida on English walnut and its Paradox rootstock in California. Plant Dis. 2015, 99, 1183. [CrossRef]

40. Hadziabdic, D.; Vito, L.M.; Windham, M.T.; Pscheidt, J.W.; Trigiano, R.N.; Kolarik, M. Genetic differentiation and spatial structure of Geosmithia morbida, the causal agent of thousand cankers disease in black walnut (Juglans nigra). Curr. Genet. 2014, 60, 75-87. [CrossRef] [PubMed]

41. Freeland, E. Intraspecific Variability of Geosmithia morbida the Causal Agent of Thousand Cankers Disease, and Effects of Temperature, Isolate and Host Family (Juglans nigra) on Canker Development. Master's Thesis, Colorado State University, Fort Collins, CO, USA, 2007.

42. Anagnostakis, S.L. Chestnut Blight: The Classical Problem of an Introduced Pathogen. Mycologia 1987, 79, 23-37. [CrossRef]

43. Brasier, C.M. Ophiostoma novo-ulmi sp. nov.; causative agent of current Dutch elm disease pandemics. Mycopathologia 1991, 115, 151-161. [CrossRef]

44. Tsui, C.K.; Roe, A.D.; El-Kassaby, Y.A.; Rice, A.V.; Alamouti, S.M.; Sperling, F.A.; Cooke, J.E.; Bohlmann, J.; Hamelin, R.C. Population structure and migration pattern of a conifer pathogen, Grosmannia clavigera, as influenced by its symbiont, the mountain pine beetle. Mol. Ecol. 2012, 21, 71-86. [CrossRef] [PubMed]

45. Goss, E.M.; Larsen, M.; Vercauteren, A.; Werres, S.; Heungens, K.; Grünwald, N.J. Phytophthora ramorum in Canada: Evidence for migration within North America and from Europe. Phytopathology 2011, 101, 166-171. [CrossRef] [PubMed]

46. Blackman, M.W. The Genus Pityophthorus Eichh. in North America: A Revisional Study of the Pityophthori, with Descriptions of Two New Genera and Seventy-one Species; New York State College of Forestry at Syracuse University: Syracuse, NY, USA, 1928.

47. Bright, D.E. Taxonomic Monograph of the Genus Pitypohthorus Eichhoff In North and Central America (Coleoptera: Scolytidae). Mem. Entomol. Soc. Can. 1981, 113, 1-378. [CrossRef]

48. Wood, S.L.; Bright, D.E., Jr. A catalogue of Scolytidae and Platypodidae (Coleoptera). Part 2, Volumes A \& B. Great. Basin Nat. Mem. 1992, 13, 1005.

49. Seybold, S.J.; Coleman, T.W.; Dallara, P.L.; Dart, N.L.; Graves, A.D.; Pederson, L.A.; Spichiger, S.-E. Recent collecting reveals new state records and geographic extremes in the distribution of the walnut twig beetle, Pityophthorus juglandis Blackman (Coleoptera: Scolytidae), in the United States. Pan-Pac. Entomol. 2012, 88, 277-280. [CrossRef]

50. Haun, G.; Powell, S.; Strohmeier, C.; Kirksey, J. State of Tennessee thousand cankers disease action plan. Tennessee Dep. Agric. 2010. Available online: http://www.protecttnforests.com/documents/TCD_ ActionPlan.pdf (accessed on 18 August 2016).

51. Cranshaw, W.; Tisserat, N. Questions and Answers about Thousand Cankers Disease of Walnut. Available online: http://www.thousandcankers.com/media/docs/CSU_TCD_FAQ_7_2012.pdf (accessed on 12 July 2016).

52. Leslie, C.A.; Seybold, S.J.; Graves, A.D.; Cranshaw, W.; Tisserat, N. Potential impacts of thousand cankers disease on commercial walnut production and walnut germplasm conservation. In VI International Walnut Symposium 861; International Society for Horticultural Science: Leuven, Belgium, 2009; pp. 431-434. [CrossRef] 
53. Cranshaw, W. The walnut twig beetle and its association with 1000 cankers disease of walnut. In Metamorphosis-A New Beginning, Proceedings of the 56th Annual Meeting of the Entomological Society of America, Reno, NV, USA, 16-19 November 2008.

54. Nix, K.A. The Life History and Control of Pityophthorus juglandis Blackman on Juglans nigra L. in Eastern Tennessee. Master's Thesis, University of Tennessee, Knoxville, TN, USA, 2013.

55. Ginzel, M. WTB TCD. Available online: https://www.youtube.com/watch?v=Tta4SGdR_tM (accessed on 15 August 2016).

56. Graves, A.D.; Coleman, T.W.; Flint, M.L.; Seybold, S.J. Walnut twig beetle and thousand cankers disease: Field identification guide. UC IPM Progr. Univ. Calif. Agric. Nat. Resour. 2009. Available online: http:/ / www.ipm.ucdavis.edu/thousandcankers (accessed on 25 July 2016).

57. Lambdin, P.; Nix, K.; Grant, J.; Pauslen, D.; Merten, P. Natural Enemies of the Walnut Twig Beetle in Eastern Tennessee. Int. J. Agric. For. 2015, 2, 31-39.

58. Chen, Y.; Seybold, S.J. Crepuscular flight activity of an invasive insect governed by interacting abiotic factors. PLoS ONE 2014, 9, e105945. [CrossRef] [PubMed]

59. Luna, E.K.; Sitz, R.A.; Cranshaw, W.S.; Tisserat, N.A. The Effect of Temperature on Survival of Pityophthorus juglandis (Coleoptera: Curculionidae). Environ. Entomol. 2013, 42, 1085-1091. [CrossRef] [PubMed]

60. Klingeman, W.E.; Lambdin, P.L.; Wiggins, G.J. Independent Urban Landscape Collection and Field Monitoring of Pityophthoris juglandis Beetles in East Tennessee. University of Tennessee: Knoxville, TN, USA, 2016; Unpublished data.

61. Tisserat, N. Stem Canker of Black-Walnut Caused by Fusarium solani in Kansas. Plant Dis. 1987, 71. [CrossRef]

62. Toole, E.R. Cottonwood canker caused by Fusarium solani. Plant Rep. 1963, 47, 1032-1036.

63. Vujanovic, V.; Cogliastro, A.; St-Arnaud, M.; Neumann, P.; Gagnon, D. First Report of Fusarium solani Canker and Wilt Symptoms on Red Oak (Quercus rubra) in Quebec, Canada. Plant Dis. 1999, 83, 78. [CrossRef]

64. Chen, W.; Swart, W.J. First report of stem canker of English walnut caused by Fusarium solani in South Africa. Plant Dis. 2000, 84, 592. [CrossRef]

65. Seybold, S.J.; Dallara, P.L.; Hishinuma, S.M.; Flint, M.L. Detecting and Identifying the Walnut Twig Beetle: Monitoring Guidelines for the Invasive Vector of Thousand Cankers Disease of Walnut. UC IPM Progr. Univ. Calif. Agric. Nat. Resour. 2012. Available online: http://www.ipm.ucdavis.edu/thousandcankers (accessed on 25 July 2016).

66. Downie, N.M.; Arnett, R.H. The Beetles of Northeastern North America. 1. Introduction; Suborders Archostemata, Adephaga, and Polyphaga, thru Superfamily Cantharoidea; Sandhill Crane Press: Gainesville, FL, USA, 1996.

67. Leavengood, J.M., Jr. The Checkered Beetles (Coleoptera: Cleridae) of Florida. Master's Thesis, University of Florida, Gainesville, FL, USA, 2008.

68. Wiggins, G.J.; Grant, J.F.; Lambdin, P.L.; Merten, P.; Nix, K.A.; Hadziabdic, D.; Windham, M.T. Discovery of Walnut Twig Beetle, Pityophthorus juglandis, Associated with Forested Black walnut, Juglans nigra, in the Eastern U.S. Forests 2014, 5, 1185-1193. [CrossRef]

69. Mayfield, A.E., III; Fraedrich, S.W.; Taylor, A.; Merten, P.; Myers, S.W. Efficacy of Heat Treatment for the Thousand Cankers Disease Vector and Pathogen in Small Black Walnut Logs. J. Econ. Entomol. 2014, 107, 174-184. [CrossRef] [PubMed]

70. Sitz, R. Management Options for the Walnut Twig Beetle, Pityophthorus juglandis Blackman, Vector of the Fungal Canker Pathogen Geosmithia morbida. Master's Thesis, Colorado State University, Fort Collins, CO, USA, 2007.

71. Audley, J.; Mayfield, A.E.; Myers, S.W.; Taylor, A.; Klingeman, W.E. Phytosanitation methods influence posttreatment colonization of Juglans nigra logs by Pityophthorus juglandis (Coleoptera: Curculionidae: Scolytinae). J. Econ. Entomol. 2016, 109, 213-221. [CrossRef] [PubMed]

72. Audley, J.; Taylor, A.; Klingeman, W.E.; Mayfield, A.E.; Myers, S.W. Insecticide dip treatments to prevent walnut twig beetle colonization of black walnut logs. For. Prod. J. 2015. [CrossRef]

73. Thousand Cankers Disease (TCD). Available online: https://www.tn.gov/agriculture/topic/ag-businesses-tcd (accessed on 12 August 2016).

74. Walnut Twig Beetle. Available online: http://codes.ohio.gov/oac/901\%3A5-58 (accessed on 12 August 2016). 
75. Virginia Department of Agriculture and Consumer Services. Diseases of Regulatory Concern. Available online: http://www.vdacs.virginia.gov/plant-industry-services-diseases-of-regulatory-concern.shtml (accessed on 12 August 2016).

76. Wilson, P. News Release: Haywood County Wood Products under NCDA\&CS Quarantine for Thousand Cankers Disease. Available online: http:/ /www.ncagr.gov/paffairs/release/2013/1-13-Thousand-CankersQuarantine-Haywood-County.htm (accessed on 12 August 2016).

77. Minnesota Department of Agriculture. Thousand Cankers Disease of Walnut. Available online: http://www.mda.state.mn.us/plants/plantdiseases/1000cankers.aspx (accessed on 12 August 2016).

78. Conrad, A.O.; Taylor, N.J.; Bonello, P. Thousand Cankers Disease. Available online: http://ohioline.osu. edu/factsheet/plpath-tree-07-0 (accessed on 19 August 2016).

79. Office of the Federal Register. Tolerances and Exemptions for Pesticide Chemicals Residues in Food-Specific Tolerances. Available online: https:/ /www.law.cornell.edu/cfr/text/40/part-180/subpart-C (accessed on 1 November 2016).

80. Nix, K.; Lambdin, P.; Grant, J.; Coots, C.; Merten, P. Concentration Levels of Imidacloprid and Dinotefuran in Five Tissue Types of Black walnut, Juglans nigra. Forests 2013, 4, 887-897. [CrossRef]

81. Elbert, A.; Nauen, R.; Leicht, W. Imidacloprid, a novel chloronicotinyl insecticide: Biological activity and agricultural importance. In Insecticides with Novel Modes of Action; Ishaaya, I., Degheele, D., Eds.; Springer: Berlin, Germany, 1998; pp. 50-73. [CrossRef]

82. Kodaka, K.; Kinoshita, K.; Wakita, T.; Yamada, E.; Kawahara, N.; Yasui, N. MTI-446: A Novel Systemic Insect Control Compound. In Proceedings of the Brighton Crop Protect Conference-Pests and Diseases; British Crop Protection Council: Farham, UK, 1998; pp. 616-632.

83. Whitehorn, P.R.; O'Connor, S.; Wackers, F.L.; Goulson, D. Neonicotinoid pesticide reduces bumble bee colony growth and queen production. Science 2012, 336, 351-352. [CrossRef] [PubMed]

84. Meyling, N.V.; Eilenberg, J. Ecology of the entomopathogenic fungi Beauveria bassiana and Metarhizium anisopliae in temperate agroecosystems: Potential for conservation biological control. Biol. Control 2007, 43, 145-155. [CrossRef]

85. Carrillo, D.; Duncan, R.E.; Peña, J.E. Ambrosia Beetles (Coleoptera: Curculionidae: Scolytinae) that Breed in Avocado Wood in Florida. Fla. Entomol. 2012, 95, 573-579. [CrossRef]

86. Fisher, J.J.; Hajek, A.E. The Effect of Maturation and Aging on Fungal Infection in the Asian Longhorned Beetle, Anoplophora glabripennis. In Proceedings of the 24th USDA Interagency Research Forum on Invasive Species, Annapolis, MD, USA, 8-11 January 2013; p. 68.

87. Sweeney, J.; Silk, P.J.; Hughes, C.; Levallée, R.; Blais, M.; Guertin, C. Auto-Dissemination of Beauveria bassiana for Control of Brown Spruce Longhorned Beetle, Tetropium fuscum (F.), Coleoptera: Cerambycidae. In Proceedings of the 24th USDA Interagency Research Forum on Invasive Species, Annapolis, MD, USA, 8-11 January 2013; p. 98.

88. Carroll, G. Fungal Endophytes in Stems and Leaves: From Latent Pathogen to Mutualistic Symbiont. Ecology 1988, 69, 2-9. [CrossRef]

89. Jakobs-Schönwandt, D.; Lohse, R.; Patel, A.V. Cultivation and formulation of an endophytic Beauveria bassiana strain. In Proceedings of the 2011 American Phytopathological Society Annual Meeting, Honolulu, HI, USA, 6-10 August 2011.

90. Lestari, A.; Rao, S. Isolation and pathogenicity of naturally-occurring entomopathogenic fungi to unique bark beetle field crop pest. In 2014 Annual Meeting of the Entomological Society of America: Science Impacting a Connected World, Proceedings of the 63rd Annual Meeting of the Entomological Society of America, Minneapolis, MN, USA, 10-13 November 2013.

91. Arnold, A.E.; Mejía, L.C.; Kyllo, D.; Rojas, E.I.; Maynard, Z.; Robbins, N.; Herre, E.A. Fungal endophytes limit pathogen damage in a tropical tree. Proc. Natl. Acad. Sci. USA 2003, 100, 15649-15654. [CrossRef] [PubMed]

92. Ownley, B.H.; Dee, M.M.; Gwinn, K.D. Effect of conidial seed treatment rate of entomopathogenic Beauveria bassiana 11-98 on endophytic colonization of tomato seedlings and control of Rhizoctonia disease. In Proceedings of the 2008 American Phytopathological Society Annual Meeting, Minneapolis, MN, USA, 26-30 July 2008; p. 101. 
93. Rind, D.; Goldberg, R.; Hansen, J.; Rosenzweig, C.; Ruedy, R. Potential evapotranspiration and the likelihood of future drought. J. Geophys. Res. Atmos. 1990, 95, 9983-10004. [CrossRef]

94. Wood, A.W.; Maurer, E.P.; Kumar, A.; Lettenmaier, D.P. Long-range experimental hydrologic forecasting for the eastern United States. J. Geophys. Res. Atmos. 2002, 107, 4429. [CrossRef]

(c) 2016 by the authors; licensee MDPI, Basel, Switzerland. This article is an open access article distributed under the terms and conditions of the Creative Commons Attribution (CC-BY) license (http:/ / creativecommons.org/licenses/by/4.0/). 